Available Online at ESci Journals

Journal of Plant Breeding and Genetics

ISSN: 2305-297X (Online), 2308-121X (Print)

http://www.escijournals.net/JPBG

\title{
LEAF CLIPPING AND POPULATION DENSITY EFFECTS ON GREEN FODDER AND GRAIN YIELD FOR HYBRID MAIZE (ZEA MAYS) IN BANGLADESH
}

\author{
a'Golam M. Rokon, bMd.Mahmudul H. Khan*, cMd.Maniruzzaman Bahadur, aMaruf H. Shanto, \\ dMd.Khairul Alam, eJahid Hussain, fGazi N. Hasan, fShomoresh Roy, fMd.Mainul Islam, gJuwel Halder \\ a International Maize and Wheat Improvement Center (CIMMYT), Dhaka, Bangladesh. \\ b Plant Breeding Section, Bangladesh Agricultural Research Institute, Bangladesh. \\ c Department of Crop Physiology \& Ecology, Hajee Mohammad Danesh Science and Technology University, Dinajpur, Bangladesh. \\ d Soil Science Section, Bangladesh Agricultural Research Institute, Bangladesh. \\ e HarvestPlus, 49 Rabindra Sarani, Dhaka 1230, Bangladesh. \\ f On-Farm Research Division, Bangladesh Agricultural Research Institute, Bangladesh. \\ g Secondary Education Quality and Access Enhancement Project, Ministry of Education, Bangladesh.
}

\begin{abstract}
A B S T R A C T
Smallholder farmers having fragmented lands need fodder and grains simultaneously for earning food security for their families. A study was conducted in Crop Physiology and Ecology Research Field and Laboratory at Hajee Mohammad Danesh Science and Technology University, Bangladesh during the period of March to July-2013 to investigate the effect of leaf clipping and population density on fodder and grain yield in maize. Three population densities (D1= $75 \mathrm{~cm} \times 25$ $\mathrm{cm}, \mathrm{D} 2=60 \mathrm{~cm} \times 20 \mathrm{~cm}$ and D3= $50 \mathrm{~cm} \times 20 \mathrm{~cm})$ and three clipping treatments $(\mathrm{C} 1=$ no clipping, $\mathrm{C} 2=$ removal of all leaf blades below the lowermost cob and C3 = removal of all leaf blades above the uppermost cob) at the silking stage were included as experimental treatments. The experiment was laid out in a two factors Randomized Complete Block Design (RCBD) with three replications. Results revealed that D1 required the maximum days to attain most of the phenological stages of maize. Higher population density (D3) with C3 clipping treatment gave the highest plant height, whereas D1 with non-clipping treatment gave the lowest. Highest total dry matter (TDM) was found in D2 with C1 and the lowest was found in D1 with C1 treatment. The highest yield (8.88 $\left.\mathrm{t} \mathrm{ha}^{-1}\right)$ and harvest index (36.2\%) were found in D3 treatment whereas the lowest yield (5.92 $\mathrm{t} \mathrm{ha}^{-1}$ ) in D1 population density but harvest index (32.6\%) was lowest in D2. The highest yield (8.33 $\left.\mathrm{tha}^{-1}\right)$ and harvest index (35.5\%) were obtained from C1 treatment and the lowest yield (6.55 $\left.\mathrm{t} \mathrm{ha}^{-1}\right)$ and harvest index (33.5\%) were obtained from C3 treatment. The highest fodder yield (3.33 $\mathrm{t} \mathrm{ha}^{-1}$ ) was obtained from D3 treatment and the lowest (2.11 tha $\left.\mathrm{t}^{-1}\right)$ in D1 treatment. In C2 treatment, the highest amount of fodder $\left(4.67 \mathrm{tha}^{-1}\right)$ was obtained. The interaction between population density and leaf clipping treatment showed a significant variation among the yield and yield attributes in maize. It is indicated that D3 and C1 combination showed the best performance in respect of grain yield ( $\left.9.67 \mathrm{t} \mathrm{ha}^{-1}\right)$ and harvest index (38.3\%) of maize. But for both grain and fodder yield, D3 with C2 showed the best performance.
\end{abstract}

Keywords: Defoliation, yield, green fodder, leaf clipping and Zea mays.

\section{INTRODUCTION}

Maize (Zea mays L.), an important cereal crop over the world, is now well-fits in diversified cropping systems in the Indo-Gangetic plains (Gathala et al., 2015). Its demand is increasing day by day as various food items, fodder for livestock, feed for poultry, and fuel and raw materials for
* Corresponding Author:
Email: mhasan.bari12@gmail.com
(C) 2019 ESci Journals Publishing. All rights reserved.

industry (Shiferaw et al., 2011; Valbuena et al., 2012) (Gathala et al., 2015). Maize production (as well as other cereals) doubled in the past 40 years due to increased yields resulting from the use of improved crop varieties, along with greater inputs of fertilizer, water and pesticides (Evenson and Gollin, 2003). Maize is one of the most important food crops in the world and, together with rice and wheat, provides at least $30 \%$ of the food calories to more than 4.5 billion people in 94 developing 
countries (FAO, 2016). Its grain can be used for human consumption in various ways, such as corn meal, fried grain and flour. The corn grain has high nutritive value containing $66.2 \%$ starch, $11.1 \%$ protein, $7.12 \%$ oil and $1.5 \%$ minerals. Moreover, it contains 90 mg carotene, 1.8 $\mathrm{mg}$ niacin, $0.8 \mathrm{mg}$ thiamin and $0.1 \mathrm{mg}$ riboflavin per $100 \mathrm{~g}$ grains (Chowdhury and Islam, 1993). Maize oil is used as the best quality edible oil. The green parts of the plant and grain are used as livestock and poultry feed, respectively. Stover and dry leaves are used as good fuel for cooking (Ahmed, 1994). Like many other parts in the world (Shiferaw et al., 2011), market demand for maize in South Asia and Bangladesh has significantly increased in the last decade as a result of the expanding poultry and fish feed industries, and for use in processed foods (Ali et al., 2008; Timsina et al., 2011). The increasing use and demand for maize have caused an escalation of area and production substantially in the region. This trend has been especially remarkable in Bangladesh, where cultivated land area with maize jumped from $0.05 \mathrm{M}$ ha in (2000) to $>0.33 \mathrm{M}$ ha in 2016. Almost all maize grown in Bangladesh is hybrid, with the average yield being highest among the South Asian countries (FAO, 2016). Excluding Pakistan, for which exact area data for rice-maize (R-M) systems are not available, these systems occupy approximately $1.31 \mathrm{M}$ ha in Bangladesh, India, and Nepal, indicating their importance in the region. Maize produces a greater quantity of epigeous mass than other cereals, so it can be used as fodder. Depending on the variety, a maize plant produces 15 to 20 leaves during its life cycle (Goldsworthy et al., 1974). Canopy structure of maize is such that adjoining leaves overlap one another and develop mutual shading. Baenziger and Glover (1980) found that mutual shading, particularly at high population density, reduces the number of grains $\mathrm{cob}^{-1}$. After anthesis, the staminate inflorescence, the tassel may have very little or no effect on grain filling (Leakey et al., 2006). Similarly, the leaves below the cob may have less contribution to grain filling as they are mutually shaded and photosynthetically less efficient. So, these organs of the plant might function as a relative sink rather than a source (Khaliliaqdam et al., 2012). The removal of these relative sink organs may play an important role in reducing competition for assimilates. Furthermore, the growers can get some green fodder for their animal (Shiferaw et al., 2011; Leakey et al., 2006).

Yield is a function of inter-plant and intra-plant competitions. Competitions associated with different plant population alter plant morphology in various ways (Abuzar et al., 2011). Researchers have shown that weaker plants become barren when plant population was increased. These plants utilized water and nutrients but contributed to lower yield (Sangoi, 2001). As such, there is considerable scope for increasing yield by adjusting the plant population to an optimum level (Lomte and Khuspe, 1987). Adjustment of proper plant spacing in the maize field is important to ensure maximum utilization of solar energy by the crop and reduce evaporation of soil moisture(FAO, 2012). Radiation intercepted by the leaf surface and the efficiency or its use in developing biomass govern the total dry matter production. Optimum population levels should be maintained to exploit maximum natural resources, such as nutrients, sunlight, soil moisture etc. and to ensure satisfactory yield (Mariscal et al., 2000). Very closest planting is undesirable because it encourages inter-plant competition for resources.

Biomass production of a crop largely depends on the function of leaf area development and consequential photosynthetic activity (Abuzar et al., 2011; Sangoi, 2001; Natr, 1992). The present study was, therefore, undertaken to assess the growth and yield response of maize with higher levels of plant population and different degrees of defoliation for finding out the effect of population density and leaf clipping on yield (fodder and grain) and yield attributes of hybrid maize.

\section{MATERIALS AND METHODS}

A field experiment was conducted at the experimental farm of the Department of Crop Physiology and Ecology at Hajee Mohammed Danesh Science and Technology University, Basherhat, Dinajpur, Bangladesh, during Kharif-1 season (the season stretching from the middle of March to the end of June (Alam et al., 2014). The experiment was laid out in two factors randomized complete block design (RCBD) with three replications. The plot size was $2 \mathrm{~m} \times 1.5 \mathrm{~m}$. The total number of treatments was nine (three levels of population density and three levels of leaf clipping). In factor A: three levels of population density were used, whereas density-1 ( $\left.D_{1}\right)$ : $75 \mathrm{~cm}$ row to row $\times 25 \mathrm{~cm}$ plant to plant distance (53333 plants ha-1 ${ }^{-1}$, density-2 $\left(D_{2}\right): 60 \mathrm{~cm}$ row to row $\times 20 \mathrm{~cm}$ plant to plant distance (83333 plants ha-1) and density-3 $\left(D_{3}\right): 50 \mathrm{~cm}$ row to row $\times 20 \mathrm{~cm}$ plant to plant distance (100000 plants ha-1). In factor $B$, these were $\left(C_{1}\right)-$ No clipping, $\left(\mathrm{C}_{2}\right)$-Removal of all leaf blades below the lowermost cob at the silking stage and $\left(\mathrm{C}_{3}\right)$-Removal of 
all leaf blades above the uppermost cob at silking stage. Seeds of the maize variety, Hybrid maize 36-Super Gold, were collected from the local seed market of Dinajpur and were sown on 14 March 2013. Fertilizers such as urea, triple super phosphate (TSP), muriate of potash (MoP), gypsum, zinc sulphate and boric acid were applied @ 500 $\mathrm{kg}, 240 \mathrm{~kg}, 180 \mathrm{~kg}, 240 \mathrm{~kg}, 10 \mathrm{~kg}$ and $6 \mathrm{~kg} \mathrm{ha}^{-1}$, respectively. For each treatment, cow dung was applied @ 6 ton ( $\mathrm{t}$ ) ha- ${ }^{-1}$. One third of urea and MoP and a full dose of all other fertilizers were applied in the plots during final land preparation. Remaining urea and MoP were applied in two equal instalments at 35 and 65 days after seeding (DAS).

The application of fertilizer instalments was followed by irrigating the plots at a rate of $4 \mathrm{~cm}$. The source-sink manipulation treatments were imposed by removing the designated source-sink organs with scissors at the silking stage (at 56 days after sowing). Malathion60 EC (1 cc. in 1liter water) was sprayed on the infested plants for leaf roller and leafhopper insects, $10 \%$ Sevin dust at $10 \mathrm{~kg} \mathrm{ha}^{-}$ 1 in the form of a ring for cutworm. The removed portions of the plants of each treatment were separately dried in a drier at $70^{\circ} \mathrm{C}$ for 72 hours and weighed separately. The maize from each treatment was harvested after 103 to 106 days as the maturity varied among treatments. Five maize plants, from each unit plot, were randomly selected excepting the first row from the border for data collection. The parameters recorded from the sample plants were plant height, total dry matter (stem and leaf dry weight), cob length, cob diameter, number of grains cob $^{-1}$, grain yield plant ${ }^{-1}$, grain yield ha-1, 1000 grain weight, fodder yield plant ${ }^{-1}$ and fodder yield ha-1.

\section{RESULTS AND DISCUSSION}

Phenological stages of maize, as affected by the interaction effect of population density (D) and leaf clipping (C), is presented in Table 1.

Table 1. Phenological stages of maize as affected by population density (D) and leaf clipping (C).

\begin{tabular}{|c|c|c|c|c|}
\hline Treatments & Day to tasseling & Day to cob initiation & Days to silking & Days to maturity \\
\hline \multicolumn{5}{|c|}{ Density } \\
\hline $\mathrm{D}_{1}$ & 52.4 & $54.4 \mathrm{a}$ & $59.4 \mathrm{a}$ & $105 \mathrm{a}$ \\
\hline $\mathrm{D}_{2}$ & 51.4 & $53.4 \mathrm{a}$ & $58.4 \mathrm{a}$ & $104 \mathrm{a}$ \\
\hline $\mathrm{D}_{3}$ & 50.4 & $52.4 \mathrm{a}$ & $57.4 \mathrm{a}$ & $103 \mathrm{a}$ \\
\hline \multicolumn{5}{|c|}{ Clipping } \\
\hline $\mathrm{C}_{1}$ & 51.3 & 53.3 & 58.3 & $105 \mathrm{a}$ \\
\hline $\mathrm{C}_{2}$ & 51.7 & 53.7 & 58.7 & $104 \mathrm{a}$ \\
\hline $\mathrm{C}_{3}$ & 51.3 & 53.3 & 58.3 & $104 \mathrm{a}$ \\
\hline \multicolumn{5}{|c|}{ Interaction } \\
\hline $\mathrm{D}_{1} \mathrm{C}_{1}$ & 52.3 & 54.3 & 59.3 & $105 \mathrm{a}$ \\
\hline $\mathrm{D}_{1} \mathrm{C}_{2}$ & 52.7 & 54.7 & 59.7 & $106 \mathrm{a}$ \\
\hline $\mathrm{D}_{1} \mathrm{C}_{3}$ & 52.3 & 54.3 & 59.3 & $105 \mathrm{a}$ \\
\hline $\mathrm{D}_{2} \mathrm{C}_{1}$ & 51.3 & 53.3 & 58.3 & $105 \mathrm{a}$ \\
\hline $\mathrm{D}_{2} \mathrm{C}_{2}$ & 51.7 & 53.7 & 58.7 & $104 \mathrm{a}$ \\
\hline $\mathrm{D}_{2} \mathrm{C}_{3}$ & 51.3 & 53.3 & 58.3 & $104 \mathrm{a}$ \\
\hline $\mathrm{D}_{3} \mathrm{C}_{1}$ & 50.3 & 52.3 & 57.3 & $104 \mathrm{a}$ \\
\hline $\mathrm{D}_{3} \mathrm{C}_{2}$ & 50.7 & 52.7 & 57.7 & $103 \mathrm{a}$ \\
\hline $\mathrm{D}_{3} \mathrm{C}_{3}$ & 50.3 & 52.3 & 57.3 & $103 \mathrm{a}$ \\
\hline CV (\%) & $2.9 \%$ & $2.8 \%$ & $2.8 \%$ & $1.4 \%$ \\
\hline LSD & ns & ns & ns & ns \\
\hline
\end{tabular}

In column values having the same letter(s) do not differ significantly at $5 \%$ level by DMRT. ns means non-significant. $\mathrm{D}_{1}=75 \mathrm{~cm}$ row to row $\times 25 \mathrm{~cm}$ plant to plant distance, $\left(53333\right.$ plants $\left.\mathrm{ha}^{-1}\right)$

$\mathrm{D}_{2}=60 \mathrm{~cm}$ row to row $\times 20 \mathrm{~cm}$ plant to plant distance, $\left(83333\right.$ plants ha $\left.{ }^{-1}\right)$

$\mathrm{D}_{3}=50 \mathrm{~cm}$ row to row $\times 20 \mathrm{~cm}$ plant to plant distance, $(100000$ plants ha-1)

$\mathrm{C}_{1}=$ No clipping.

$\mathrm{C}_{2}=$ Removal of all leaf blades below the lowermost cob at silking stage.

$\mathrm{C}_{3}=$ Removal of all leaf blades above the uppermost cob at silking stage. 
Neither the days to tasseling varied among the treatments of change in plant densities nor among leaf clipping and among the combinations of plant density and leaf clipping treatments on days to tasseling. Days to cob initiation, Days to silking and days to maturity were also not significantly influenced by plant density and leaf clipping and by their combinations. These results are dissimilar to the results of Hus and Huang (1984), and Rathore et al. (1976). The results of not having differences in phonological stages can be attributed by many reasons for example, the variety has these days required reaching to the corresponding stages and to the timing of clipping treatment inducement. The treatments of leaf clipping were employed at the silking stage of the crop which in the meantime had maximum vegetative growth and dry matter accumulation.

Different plant density showed varied plant heights at 30 and 60 DAS. At 90 DAS, the plant density in combination with leaf clipping had varied plant height. The tallest plant was recorded with medium plant density (83333 plants ha-1) in combination with removed leaf blades above the uppermost cob (Table 2), while the lowest was from low population-maintained plots with no clipping. Total dry matter production varied significantly due to different plant density and clipping. The highest total dry matter $\left(1.65 \mathrm{~kg} \mathrm{~m}^{-2}\right)$ was found in the plot where 83333 plants were maintained ha-1 $\left(\mathrm{D}_{2}\right)$. The lowest total dry matter $\left(1.18 \mathrm{~kg} \mathrm{~m}^{-2}\right)$ was found in the plot where 53333 plants were maintained ha-1 $\left(D_{1}\right)$. We observed that among the clipping treatments, the variation of total dry matter $\left(\mathrm{gm}^{-2}\right)$ was not significant. Interaction effect of plant density and leaf clipping showed a significant effect on a total dry matter $\left(\mathrm{gm}^{-2}\right)$.

Table 2. Plant height and total dry matter (TDM) of maize affected by plant density and clipping treatment.

\begin{tabular}{|c|c|c|c|c|}
\hline \multirow{2}{*}{ Treatment } & \multicolumn{3}{|c|}{ Plant height $(\mathrm{cm})$} & \multirow{2}{*}{$\begin{array}{l}\text { Total dry matter (TDM) } \\
\mathrm{Kg} \mathrm{m}^{-2}\end{array}$} \\
\hline & 30DAS & 60DAS & 90DAS & \\
\hline \multicolumn{5}{|c|}{ Density } \\
\hline $\mathrm{D}_{1}$ & $101.3 \mathrm{~b}$ & $164.8 \mathrm{~b}$ & $226 \mathrm{a}$ & $1.18 \mathrm{~b}$ \\
\hline $\mathrm{D}_{2}$ & $111.8 \mathrm{a}$ & $175.3 \mathrm{a}$ & $242 \mathrm{a}$ & $1.65 \mathrm{a}$ \\
\hline $\mathrm{D}_{3}$ & $117.3 \mathrm{a}$ & $180.8 \mathrm{a}$ & $242 \mathrm{a}$ & $1.56 \mathrm{a}$ \\
\hline \multicolumn{5}{|c|}{ Clipping } \\
\hline $\mathrm{C}_{1}$ & 107.8 & 171.3 & $232 \mathrm{a}$ & $1.54 \mathrm{a}$ \\
\hline $\mathrm{C}_{2}$ & 110.1 & 173.6 & $235 \mathrm{a}$ & $1.51 \mathrm{a}$ \\
\hline $\mathrm{C}_{3}$ & 112.5 & 176.0 & $242 \mathrm{a}$ & $1.34 \mathrm{a}$ \\
\hline \multicolumn{5}{|c|}{ Interactions } \\
\hline $\mathrm{D}_{1} \mathrm{C}_{1}$ & 98.2 & 161.7 & $223 \mathrm{~b}$ & $1.11 \mathrm{e}$ \\
\hline $\mathrm{D}_{1} \mathrm{C}_{2}$ & 104.1 & 167.6 & $229 \mathrm{~b}$ & $1.24 \mathrm{de}$ \\
\hline $\mathrm{D}_{1} \mathrm{C}_{3}$ & 101.6 & 165.1 & $226 \mathrm{~b}$ & $1.20 \mathrm{de}$ \\
\hline $\mathrm{D}_{2} \mathrm{C}_{1}$ & 110.1 & 173.6 & $235 \mathrm{ab}$ & $1.96 \mathrm{a}$ \\
\hline $\mathrm{D}_{2} \mathrm{C}_{2}$ & 109.2 & 172.7 & $234 \mathrm{ab}$ & $1.63 \mathrm{~b}$ \\
\hline $\mathrm{D}_{2} \mathrm{C}_{3}$ & 116.0 & 179.5 & $257 \mathrm{a}$ & $1.35 \mathrm{~cd}$ \\
\hline $\mathrm{D}_{3} \mathrm{C}_{1}$ & 115.1 & 178.6 & $240 \mathrm{ab}$ & $1.56 \mathrm{~b}$ \\
\hline $\mathrm{D}_{3} \mathrm{C}_{2}$ & 116.8 & 180.3 & $241 \mathrm{ab}$ & $1.66 \mathrm{~b}$ \\
\hline $\mathrm{D}_{3} \mathrm{C}_{3}$ & 119.8 & 183.3 & $244 \mathrm{ab}$ & $1.48 \mathrm{bc}$ \\
\hline CV (\%) & $4.50 \%$ & $2.85 \%$ & $5.2 \%$ & $7.9 \%$ \\
\hline LSD & 8.6 & 8.6 & 21.1 & 0.20 \\
\hline
\end{tabular}

In column values having the same letter(s) do not differ significantly at $5 \%$ level by DMRT.

$D_{1}=75 \mathrm{~cm}$ row to row $\times 25 \mathrm{~cm}$ plant to plant distance, $\left(53333\right.$ plants $\left.\mathrm{ha}^{-1}\right)$

$\mathrm{D}_{2}=60 \mathrm{~cm}$ row to row $\times 20 \mathrm{~cm}$ plant to plant distance, $\left(83333\right.$ plantsha- $\left.{ }^{-1}\right)$

$\mathrm{D}_{3}=50 \mathrm{~cm}$ row to row $\times 20 \mathrm{~cm}$ plant to plant distance, $\left(100000\right.$ plantsha $\left.^{-1}\right)$

$\mathrm{C}_{1}=$ No clipping.

$\mathrm{C}_{2}=$ Removal of all leaf blades below the lowermost cob at silking stage.

$\mathrm{C}_{3}=$ Removal of all leaf blades above the uppermost cob at silking stage. 
Highest total dry matter $\left(2.0 \mathrm{~kg} \mathrm{~m}^{-2}\right)$ was observed in (60 $\mathrm{cm} \times 20 \mathrm{~cm}$ spacing where 83333 plants ha-1 were maintained with no clipping $\left(\mathrm{D}_{2} \mathrm{C}_{1}\right)$. Lowest total dry matter $\left(1.11 \mathrm{~kg} \mathrm{~m}^{-2}\right)$ was found in $\mathrm{D}_{1} \mathrm{C}_{1}$ where a minimum number of plants was grown, and no clipping was done. This was statistically similar to $\mathrm{D}_{1} \mathrm{C}_{2}$ and $\mathrm{D}_{1} \mathrm{C}_{3}$ treatments. Cob length varied significantly among population density treatments (Table 3). The highest cob length $(17.7 \mathrm{~cm})$ was found in $\mathrm{D}_{1}$ whereas the lowest cob length value $(16.4 \mathrm{~cm})$ was recorded in $\mathrm{D}_{3}$. Cob length was nonsignificant due to leaf clipping (Table 3), while the interaction effect of population density and leaf clipping showed a significant effect on cob length (Table 3). The highest value of cob length $(17.9 \mathrm{~cm})$ was recorded in $\mathrm{D}_{1} \mathrm{C}_{1}$ treatment (the treatment with wider plant spacing and no clipping) which was statistically similar to $\mathrm{D}_{1} \mathrm{C}_{2}$, $\mathrm{D}_{1} \mathrm{C}_{3}, \mathrm{D}_{2} \mathrm{C}_{1}$, and $\mathrm{D}_{2} \mathrm{C}_{2}$. The lowest cob length $(16.010 \mathrm{~cm})$ was found in $\mathrm{D}_{3} \mathrm{C}_{2}$ (the treatment with the shorter plant spacing and leaf removed below the lowermost cob) which was similar to $\mathrm{D}_{3} \mathrm{C}_{3}$ (the treatment with the shorter plant spacing and leaf removed above the upper-most cob). Other combination showed the intermediate values. Similar findings were reported by Osorio (1976), Loesch et al. (1976), Rathore et al. (1976) and Remison (1978). The diameter of cob was decreased significantly with the increasing level of population density. The highest cob diameter $(5.05 \mathrm{~cm})$ was found in $\mathrm{D}_{1}$ followed by $\mathrm{D}_{2}$. The lowest cob diameter $(4.07 \mathrm{~cm})$ was found in $\mathrm{D}_{3}$. Leaf clipping did not significantly affect the cob diameter. Interaction effects of population density and leaf clipping showed a significant effect on cob diameter. The highest cob diameter $(5.17 \mathrm{~cm})$ was recorded in $\mathrm{D}_{1} \mathrm{C}_{2}$ which was also similar to $\mathrm{D}_{1} \mathrm{C}_{1}, \mathrm{D}_{1} \mathrm{C}_{3}, \mathrm{D}_{2} \mathrm{C}_{1}$ and $\mathrm{D}_{2} \mathrm{C}_{2}$. The lowest cob diameter $(3.96 \mathrm{~cm})$ was found in $\mathrm{D}_{3} \mathrm{C}_{2}$ which was also similar to $\mathrm{D}_{3} \mathrm{C}_{1}$ and $\mathrm{D}_{3} \mathrm{C}_{3}$. A gradual reduction was observed in number of grains cob $^{-1}$ with the increasing level of plant density. The maize produced highest grains cob $^{-1}$ (434) was found in $D_{1}$ which was as par with $D_{2}$ and $\mathrm{D}_{3}$ but there was no significant difference. A similar result was given by Hus and Huang (1984) who reported that number of grains $\mathrm{cob}^{-1}$ was different under different plant densities and decreased as plant density increased. Leaf clipping had little effects on decreasing the number of grains cob $^{-1}$ but there was no significant difference in number of grains $\mathrm{cob}^{-1}$. The maximum number of grains $\operatorname{cob}^{-1}$ (421) was recorded in $\mathrm{C}_{2}$ treatment which was at par with $\mathrm{C}_{1}$ and $\mathrm{C}_{2}$ treatments. Interaction effects of plant density and leaf clipping showed a significant effect on number of grains $\mathrm{cob}^{-1}$. The highest number of grains per cob $^{-1}$ (456) was obtained from $\mathrm{D}_{1} \mathrm{C}_{2}$ and the lowest number of grains $\mathrm{cob}^{-1}$ (391) was obtained from $\mathrm{D}_{3} \mathrm{C}_{2}$. Grain yield plant ${ }^{-1}$ is the product of number of cobs plants, grains $\mathrm{cob}^{-1}$ and individual grain weight. A positive change in any one of these characters due to density and clipping treatment might provide a detailed appraised for the reasons for increasing grain yield plant ${ }^{-1}$. Maize plant was influenced significantly by the different density levels (Table 3). Grain yield ha-1 was increased gradually with the increasing level of density. The plant gave the highest grain yield ( $8.8 \mathrm{t} \mathrm{ha}^{-1}$ ) in $\mathrm{D}_{3}$ and the lowest grain yield ha-1 $\left(5.9\right.$ t ha $\left.^{-1}\right)$ was obtained from $D_{1}$. These findings are in line with the findings of Ahmad and Muhammad (1999). The leaf clipping played a significant role in grain yield ha-1. The highest grain yield ha-1 $(8.33 \mathrm{t})$ was found in $\mathrm{C}_{1}$ which was similar to $\mathrm{C}_{2}$ and the lowest grain yield $\mathrm{ha}^{-1}(6.55 \mathrm{t})$ was obtained from $\mathrm{C}_{3}$. Interaction of plant density and leaf clipping showed a significant effect on grain yield per hectare. The highest grain yield ha-1 ${ }^{-1} 9.67$ t) was found in $\mathrm{D}_{3} \mathrm{C}_{1}$ which was as par with $\mathrm{D}_{3} \mathrm{C}_{2}$ the lowest grain yield ha-1 $\left(4.68 \mathrm{t}\right.$ ) from $\mathrm{D}_{1} \mathrm{C}_{3}$. Similar results were also reported by Hassen and Chauhan (2003).

Significant variations were found in 1000- grain weight among different population density levels. The highest 1000- grain weight ( $263 \mathrm{~g}$ ) was found in $\mathrm{D}_{1}$ and the lowest 1000- grain weight (228 g) was found in $\mathrm{D}_{3}$ which was statistically similar to D2. Wilson and Allison (1978) found that increasing plant density decreased grain size. The leaf clipping also affects the 1000- grain weight significantly. The highest 1000 - grain weight ( $267 \mathrm{~g}$ ) was obtained from $\mathrm{C}_{1}$ and the lowest 1000 - grain weight (215 g) obtained from $\mathrm{C}_{3}$ Interaction effects of population density and leaf clipping showed significant effects on 1000-grain weight. The highest 1000- grain weight (313 g) was obtained from $\mathrm{D}_{1} \mathrm{C}_{1}$ and the lowest 1000 - grain weight $(211 \mathrm{~g})$ was obtained from $\mathrm{D}_{3} \mathrm{C}_{3}$ which was as par with $\mathrm{D}_{2} \mathrm{C}_{3}$.

The leaf blades which were obtained from the plant after clipping can be used as fodder for the animal. The fodder yield plant ${ }^{-1}$ was influenced significantly by the different plant density level. Fodder yield plant $^{-1}$ was decreased significantly with the increasing level of plant density. The highest fodder yield plant ${ }^{-1}$ (39.6 g) was obtained from $D_{1}$ which was statistically similar to $D_{2}$ and the lowest fodder yield plant ${ }^{-1}$ (33.3 g) was obtained from $D_{3}$. Leaf clipping played a significant role in fodder yield plant $^{-1}$ among the clipping treatments, the highest fodder yield plant ${ }^{-1}(60.6 \mathrm{~g})$ was obtained from $\mathrm{C}_{2}$ and the lowest 
fodder yield plant ${ }^{-1}$ (46.7 g) was obtained from $\mathrm{C}_{3}$. Interaction effect of plant density and leaf clipping showed a significant effect on fodder yield plant ${ }^{-1}$. Among the clipping treatments, the highest fodder yield plant ${ }^{-1}$ $(68.9 \mathrm{~g})$ was obtained from $\mathrm{D}_{1} \mathrm{C}_{2}$ combination and the lowest fodder yield plant ${ }^{-1}(45.0 \mathrm{~g})$ was obtained from $\mathrm{D}_{3} \mathrm{C}_{3}$ which was statistically similar with $\mathrm{D}_{2} \mathrm{C}_{3}$ Other combination showed the intermediate results. Clipping of all leaf blades below the lowermost cob produced more fodder than clipping of all leaf blades above the cob. These findings are in line with the findings of Emran (2010). Density level and clipping treatment affects the fodder yield ha-1 (Table 3 ). The fodder yield was significantly influenced by the level of density. The highest fodder yield ha-1 $(3.33 \mathrm{t})$ was obtained from $\mathrm{D}_{3}$ and the lowest fodder yield ha-1 $\left(2.11 \mathrm{t}\right.$ ) was obtained from $\mathrm{D}_{1}$.

Leaf clipping played a great role in fodder yield ha-1 significantly. Among the clipping treatments, the highest fodder yield ha-1 $\left(4.67 \mathrm{t}\right.$ ) was obtained from $\mathrm{C}_{2}$ and the lowest fodder yield ha ${ }^{-1}(3.64 \mathrm{t})$ was obtained from $\mathrm{C}_{3}$. Interaction effect of plant density and leaf clipping showed a significant effect on fodder yield ha-1. Among the clipping treatments, the highest fodder yield ha-1 $(5.5$ t) was obtained from $\mathrm{D}_{3} \mathrm{C}_{2}$ combination and the lowest fodder yield ha-1 $(2.67 \mathrm{t})$ was obtained from $\mathrm{D}_{1} \mathrm{C}_{3}$ combination. Other combination showed the intermediate results. Clipping of all leaf blades below the lowermost cob produced more fodder than clipping of all leaf blades above the cob. Similar results were reported by Emran (2010).

Table 3. Yield and yield attributes of maize as influenced by density and clipping.

\begin{tabular}{|c|c|c|c|c|c|c|c|c|}
\hline Treatments & $\begin{array}{l}\text { Cob } \\
\text { length } \\
(\mathrm{cm})\end{array}$ & $\begin{array}{c}\text { Cob } \\
\text { diameter } \\
(\mathrm{cm})\end{array}$ & $\begin{array}{c}\text { No of } \\
\text { gains } \text { cob- }^{-1}\end{array}$ & $\begin{array}{c}\text { Grain } \\
\text { yield } \\
\left(\mathrm{kg} \mathrm{ha}^{-1}\right)\end{array}$ & $\begin{array}{c}\text { Thousand } \\
\text { grain weight } \\
\text { (g) }\end{array}$ & $\begin{array}{l}\text { Fodder } \\
\text { yield plant }{ }^{-1} \\
\text { (g) }\end{array}$ & $\begin{array}{l}\text { Fodder } \\
\text { yield } \\
\left(\mathrm{kg} \mathrm{ha}^{-1}\right)\end{array}$ & $\begin{array}{l}\text { Harvest } \\
\text { index } \\
(\%)\end{array}$ \\
\hline \multicolumn{9}{|c|}{ Density } \\
\hline $\mathrm{D}_{1}$ & $17.7 \mathrm{a}$ & $5.1 \mathrm{a}$ & $434 \mathrm{a}$ & $5.9 \mathrm{c}$ & $263 \mathrm{a}$ & $39.6 \mathrm{a}$ & $2.1 \mathrm{c}$ & $34.3 \mathrm{ab}$ \\
\hline $\mathrm{D}_{2}$ & $17.2 \mathrm{a}$ & $4.6 \mathrm{a}$ & $408 \mathrm{a}$ & $7.9 \mathrm{~b}$ & $232 b$ & $34.4 \mathrm{ab}$ & $2.9 \mathrm{~b}$ & $32.6 \mathrm{~b}$ \\
\hline $\mathrm{D}_{3}$ & $16.4 \mathrm{~b}$ & $4.1 \mathrm{~b}$ & $396 a$ & $8.9 \mathrm{a}$ & $228 \mathrm{~b}$ & $33.3 \mathrm{~b}$ & $3.3 \mathrm{a}$ & $36.2 \mathrm{a}$ \\
\hline LSD & 0.61 & 0.48 & & & & & & \\
\hline \multicolumn{9}{|c|}{ Clipping } \\
\hline $\mathrm{C}_{1}$ & $17.4 \mathrm{a}$ & $4.7 \mathrm{a}$ & $420 \mathrm{a}$ & $8.3 \mathrm{a}$ & $267 \mathrm{a}$ & $0 \mathrm{c}$ & $0 \mathrm{c}$ & $35.5 \mathrm{a}$ \\
\hline $\mathrm{C}_{2}$ & $17.0 \mathrm{a}$ & $4.6 \mathrm{a}$ & $421 \mathrm{a}$ & $7.8 \mathrm{a}$ & $241 \mathrm{~b}$ & $60.6 \mathrm{a}$ & $4.7 \mathrm{a}$ & $34.0 \mathrm{a}$ \\
\hline $\mathrm{C}_{3}$ & $17.0 \mathrm{a}$ & $4.5 \mathrm{a}$ & $397 \mathrm{a}$ & $6.5 \mathrm{~b}$ & $215 \mathrm{c}$ & $46.7 \mathrm{~b}$ & $3.6 \mathrm{~b}$ & $33.5 \mathrm{a}$ \\
\hline \multicolumn{9}{|c|}{ Interactions } \\
\hline $\mathrm{D}_{1} \mathrm{C}_{1}$ & $17.9 \mathrm{a}$ & $5.0 \mathrm{ab}$ & $447 \mathrm{a}$ & $6.8 \mathrm{~d}$ & $313 a$ & $0 \mathrm{e}$ & $0 \mathrm{e}$ & $38.1 \mathrm{a}$ \\
\hline $\mathrm{D}_{1} \mathrm{C}_{2}$ & $17.7 \mathrm{a}$ & $5.2 \mathrm{a}$ & $456 \mathrm{a}$ & $6.2 \mathrm{~d}$ & $256 \mathrm{~b}$ & $68.9 \mathrm{a}$ & $3.7 \mathrm{c}$ & $33.4 \mathrm{bcd}$ \\
\hline $\mathrm{D}_{1} \mathrm{C}_{3}$ & $17.6 \mathrm{a}$ & $5.0 \mathrm{ab}$ & $399 c$ & $4.7 \mathrm{e}$ & 220 cde & $50.0 \mathrm{~cd}$ & $2.7 \mathrm{~d}$ & $31.4 \mathrm{~cd}$ \\
\hline $\mathrm{D}_{2} \mathrm{C}_{1}$ & $17.6 \mathrm{a}$ & $4.8 \mathrm{ab}$ & $412 \mathrm{~b}$ & $8.5 \mathrm{bc}$ & $247 \mathrm{bc}$ & $0 \mathrm{e}$ & $0 \mathrm{e}$ & $30.3 \mathrm{~d}$ \\
\hline $\mathrm{D}_{2} \mathrm{C}_{2}$ & $17.3 \mathrm{ab}$ & $4.6 \mathrm{abc}$ & $415 \mathrm{~b}$ & $8.1 \mathrm{c}$ & $235 \mathrm{~b}-\mathrm{e}$ & $58.0 \mathrm{~b}$ & $4.8 \mathrm{~b}$ & $33.3 \mathrm{bcd}$ \\
\hline $\mathrm{D}_{2} \mathrm{C}_{3}$ & $16.8 \mathrm{bc}$ & $4.4 \mathrm{bcd}$ & $397 \mathrm{~d}$ & $7.0 \mathrm{~d}$ & $214 \mathrm{de}$ & $45.1 \mathrm{~d}$ & $3.8 \mathrm{c}$ & $34.2 \mathrm{bc}$ \\
\hline $\mathrm{D}_{3} \mathrm{C}_{1}$ & $16.7 \mathrm{bc}$ & $4.2 \mathrm{~cd}$ & $402 \mathrm{c}$ & $9.7 \mathrm{a}$ & 241 be & $0 \mathrm{e}$ & $0 \mathrm{e}$ & $38.3 \mathrm{a}$ \\
\hline $\mathrm{D}_{3} \mathrm{C}_{2}$ & $16.0 \mathrm{~d}$ & $4.0 \mathrm{~d}$ & $391 \mathrm{~d}$ & $9.0 \mathrm{ab}$ & 232 be & $55.0 \mathrm{bc}$ & $5.5 \mathrm{a}$ & $35.4 \mathrm{ab}$ \\
\hline $\mathrm{D}_{3} \mathrm{C}_{3}$ & $16.5 \mathrm{~cd}$ & $4.1 \mathrm{~cd}$ & $394 \mathrm{~d}$ & $7.9 \mathrm{c}$ & $211 \mathrm{e}$ & $45.0 \mathrm{~d}$ & $4.5 \mathrm{~b}$ & $34.9 \mathrm{abc}$ \\
\hline CV (\%) & $2.23 \%$ & $6.83 \%$ & $9.97 \%$ & $5.97 \%$ & $6.16 \%$ & $9.20 \%$ & $8.67 \%$ & $5.46 \%$ \\
\hline LSD & 0.66 & 0.54 & 26.8 & 0.78 & 25.7 & 5.7 & 0.42 & 3.2 \\
\hline
\end{tabular}

In column values having the same letter(s) do not differ significantly at $5 \%$ level by DMRT. D1 $=75 \mathrm{~cm}$ row to row $\times 25$ cm plant to plant distance, (53333 plants ha-1)

$\mathrm{D} 2=60 \mathrm{~cm}$ row to row $\times 20 \mathrm{~cm}$ plant to plant distance, $(83333$ plants ha-1)

D3 $=50 \mathrm{~cm}$ row to row $\times 20 \mathrm{~cm}$ plant to plant distance, $\left(100000\right.$ plants $\left.^{-1}\right)$

C1=No clipping.

$\mathrm{C} 2=$ Removal of all leaf blades below the lowermost cob at silking stage.

C3=Removal of all leaf blades above the uppermost cob at silking stage. 
The harvest index was significantly influenced by the population density (Table 3 ). The highest harvest index $(36.2 \%)$ was obtained from $\mathrm{D}_{3}$ which was at par with $\mathrm{D}_{1}$. The lowest harvest index (32.6\%) was obtained from $\mathrm{D}_{2}$. Leaf clipping played a non-significant role in harvest index. The highest harvest index (35.5\%) was obtained from $\mathrm{C}_{1}$ which was at par with $\mathrm{C}_{2}$ and $\mathrm{C}_{3}$. Interaction effect of plant density and leaf clipping showed a significant effect on harvest index of maize. The highest harvest index (38.3\%) was obtained from $\mathrm{D}_{3} \mathrm{C}_{1}$ combination which was statistically similar with $\mathrm{D}_{1} \mathrm{C}_{1} \mathrm{D}_{3} \mathrm{C}_{2}$ and $\mathrm{D}_{3} \mathrm{C}_{3}$ combination, and the lowest harvest index (30.3\%) was obtained from $\mathrm{D}_{2} \mathrm{C}_{1}$ combination which was at par with $\mathrm{D}_{1} \mathrm{C}_{3}$. Other combination showed the intermediate results.

\section{CONCLUSIONS}

Based on the results of the present study following practical applications are proposed. In the case of $\mathrm{D}_{3}$ with $\mathrm{C}_{1}$, the grain yield ha-1 is highest. The highest grain yield loss was observed in $\mathrm{D}_{1}$ with the removal of all leaf blades above the cob. In the case of both grain and fodder yield, the combination of $D_{3}$ with $C_{2}$ gave the highest benefits.

\section{REFERENCES}

Abuzar, M. R., G. U. Sadozai, M. S. Baloch, A. A. Baloch, I. H. Shah, T. Javaid and N. Hussain. 2011. Effect of plant population densities on yield of maize. The Journal of Animal \& Plant Sciences, 21: 692-95.

Ahmad, N. and F. C. Muhammad. 1999. Plant density effect on yield and quality of maize seed. Journal of Agricultural Research, 37: 25-29.

Ahmed, F. 1994. Maize Production Technology (in Bengali).International Fertilizer Development Center-Consultant of Ministry of Agriculture. Bangladesh. pp. 13-15.

Alam, M., M. Islam, N. Salahin and M. Hasanuzzaman. 2014. Effect of tillage practices on soil properties and crop productivity in wheat-mungbean-rice cropping system under subtropical climatic conditions. The Scientific World Journal, 2014: 40-55.

https://doi.org/10.1155/2014/437283

Ali, M. Y., S. R. Waddington, D. P. Hodson, J. Timsina and J. Dixon. 2008. Maize-rice cropping systems in Bangladesh: Status and research opportunities. Joint Publication of CIMMYT and IRRI. CIMMYT. Mexico. pp. 36.

Baenziger, P. S. and D. V. Glover. 1980. Effect of Reducing Plant Population on Yield and Kernel Characteristics of Sugary-2 and Normal Maize.
Crop science, 20: 444-47.

https://doi.org/10.2135/cropsci1980.0011183 $\underline{\mathrm{X} 002000040005 \mathrm{x}}$

Chowdhury, M. K. and M. A. Islam. 1993. Production and use of maizeOn-Farm Research Division, Bangladesh Agricultural Research Institute. Joydebpur, Gazipur, Bangladesh pp. 8-57.

Emran, S. A. 2010. Source-sink manipulation and population density effects on green fodder and grain yield in hybrid maize, Department of Agronomy, Bangabandhu Sheikh Mujibur Rahman Agricultural University. Gazipur, Bangladesh.

Evenson, R. E. and D. Gollin. 2003. Assessing the impact of the Green Revolution, 1960 to 2000. Science, 300: 758-62.

https://doi.org/10.1126/science.1078710

FAO. 2012. Food and Agriculture OrganizationUnited Nations. New York, United States.

FAO. 2016. Food and Agriculture OrganizationUnited Nations. New York, United States.

Gathala, M. K., J. Timsina, M. S. Islam, M. M. Rahman, M. I. Hossain, M. Harun-Ar-Rashid and A. McDonald. 2015. Conservation agriculture based tillage and crop establishment options can maintain farmers' yields and increase profits in South Asia's rice-maize systems: Evidence from Bangladesh. Field Crops Research, 172: 85-98. https://doi.org/10.1016/j.fcr.2014.12.003

Goldsworthy, P. R., A. F. E. Palmer and D. W. Sperling. 1974. Growth and yield of lowland tropical maize in Mexico. The Journal of Agricultural Science, 83: 223-30. https://doi.org/10.1017/s0021859600051893

Hassen, H. and S. S. Chauhan. 2003. Effect of rate of maize leaf defoliation at various growth stages on grain, stover yield components of maize and undersown forage production. Indian Journal of Agricultural Research, 37: 136-39.

Hus, A. and S. C. Huang. 1984. Effects of plant density on yield and agronomic characteristics of maize in spring and autumn cropping seasonTaichung District Agricultural Improvement Station. Changhua, China. pp. 13-21.

Khaliliaqdam, N., A. Soltani, T. Mir-Mahmoodi and T. Jadidi. 2012. Effect of leaf defoliation on some agronomical traits of corn. World Applied Sciences Journal, 20: 545-48. 
Leakey, A. D. B., M. Uribelarrea, E. A. Ainsworth, S. L. Naidu, A. Rogers, D. R. Ort and S. P. Long. 2006. Photosynthesis, Productivity, and Yield of Maize Are Not Affected by Open-Air Elevation of $\mathrm{CO} 2$ Concentration in the Absence of Drought. Plant Physiology, 140: 779-90. https://doi.org/10.1104/pp.105.073957

Loesch, P. J., C. F. Stark and M. S. Zuber. 1976. Effects of Plant Density on the Quality of Cobs Used for Corn Cob Pipes1. Crop science, 16: 706. https://doi.org/10.2135/cropsci1976.0011183 $\mathrm{x} 001600050027 \mathrm{x}$

Lomte, M. H. and V. S. Khuspe. 1987. Effects of plant densities, phosphorus levels and Antitranspirant on the yield of summer groundnut. Journal of Maharashtra Agricultural Universities, 12: 2830.

Mariscal, M. J., F. Orgaz and F. J. Villalobos. 2000. Radiation-use efficiency and dry matter partitioning of a young olive (Olea europaea) orchard. Tree Physiology, 20: 65-72. https://doi.org/10.1093/treephys/20.1.65

Natr, L. 1992. Mineral nutrients-a ubiquitous stress factor for photosynthesis. Photosynthetica, 27: 271-95.

Osorio, F. O. 1976. Population effect on yield and other characteristics of maize in the E-1 Zamorano Valley, Honduras. Field Crop Abstracts, 33: 192680.

Rathore, D. N., K. Singh and B. P. Singh. 1976. Effect of nitrogen and plant population on the yield attributes of maize. Indian Journal of Agricultural Research, 10: 79-82.

Remison, S. U. 1978. Effect of Defoliation During the Early
Vegetative Phase and at Silking on Growth of Maize (Zea mays L.). Annals of Botany, 42: 143945.

https://doi.org/10.1093/oxfordjournals.aob.a0 85591

Sangoi, L. 2001. Understanding Plant Density Effects on Maize Growth and Development: An Important Issue to Maximize Grain Yield. Ciência Rural, 31: 159-68.

https://doi.org/10.1590/s0103$\underline{84782001000100027}$

Shiferaw, B., B. M. Prasanna, J. Hellin and M. Bänziger. 2011. Crops that feed the world 6. Past successes and future challenges to the role played by maize in global food security. Food Security, 3: 307-27. https://doi.org/10.1007/s12571-011-0140-5

Timsina, J., R. J. Buresh, A. Dobermann and J. Dixon. 2011. Rice-Maize Systems in Asia: Current Situation and PotentialIRRI and CIMMYT. Los Banos, Philippines. pp. 232.

Valbuena, D., O. Erenstein, S. Homann-Kee Tui, T. Abdoulaye, L. Claessens, A. J. Duncan, B. Gérard, M. C. Rufino, N. Teufel, A. van Rooyen and M. T. van Wijk. 2012. Conservation Agriculture in mixed crop-livestock systems: Scoping crop residue trade-offs in Sub-Saharan Africa and South Asia. Field Crops Research, 132: 175-84. https://doi.org/10.1016/j.fcr.2012.02.022

Wilson, J. H. and J. C. S. Allison. 1978. Effect of plant population on ear differentiation and growth in maize. Annals of Applied Biology, 90: 127-32. https://doi.org/10.1111/i.17447348.1978.tb02619.x 